\title{
Por uma história ambiental das áreas naturais protegidas no Brasil
}

\author{
An environmental history of protected \\ natural areas in Brazil
}

\author{
João Rafael Moraes de Oliveira \\ Doutorando do Programa de Pós-graduação em História/Faculdade de Ciências e Letras/Universidade Estadual Paulista. \\ joaorafaelo@yahoo.com.br
}

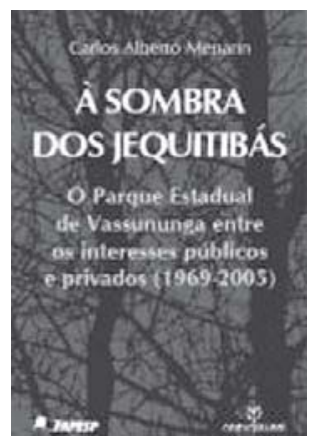

MENARIN, Carlos Alberto. À sombra dos jequitibás: o Parque Estadual de Vassununga entre os interesses públicos e privados (1969-2005). São Paulo: Annablume; Fapesp, 2011. $270 p$.
$\mathrm{N}^{2}$ a iminência de ser votado o projeto do novo Código Florestal pelo Congresso brasileiro, criticado por boa parte da comunidade científica, nacional e internacional, o livro do historiador ambiental Carlos Alberto Menarin vem lançar luzes sobre os meandros da política de criação de áreas naturais protegidas no Brasil. Seguindo na trilha do brasilianista Warren Dean (1996, p.292), que já havia constatado que, em nosso país, "a corrupção burocrática, sistêmica e generalizada descobriu nas leis ambientais um pasto verdejante", Menarin nos municia com argumentos convincentes contra o lobby ruralista que está por trás da proposta de alteração do Código Florestal, revelando aspectos até então pouco conhecidos e documentados das relações do capital privado com o Estado.

Com argúcia de um verdadeiro detetive e fugindo do romantismo ambientalista em que muitos autores do tema se embrenham, Menarin examinou com perspectiva crítica de historiador bem treinado o processo de criação do Parque Estadual de Vassununga, em Santa Rita do Passa Quatro, interior de São Paulo. Seu estudo chama a atenção para o oportunismo dos interesses do setor privado no estabelecimento de unidades de conservação que se revelaram, nesse estudo de caso, mecanismos de espoliação do bem público e de acumulação capitalista.

As inquietações que ensejaram a pesquisa, e que resultou na dissertação de mestrado do autor, defendida na Faculdade de Ciências e Letras da Unesp, campus de Assis, e depois no livro, afloraram durante a sua participação nos trabalhos para a elaboração do Plano de Manejo do Parque de Vassununga. A constatação, naquela ocasião, da limitada abrangência de uma política ambiental consequente no âmbito local, despertou no pesquisador o interesse para essa investigação.

Carlos Menarin explorou a senda aberta pelos historiadores ambientais, especialmente na perspectiva de Donald Worster (1991, p.200), que definiu como tarefa principal desses historiadores "aprofundar o entendimento de como os seres humanos foram, através dos tempos, afetados pelo seu ambiente natural, e, inversamente, como eles afetaram esse 
ambiente e com que resultados". Do ponto de vista metodológico, vale ressaltar a influência, em seu trabalho, do geógrafo Christian Brannstrom, que centra suas pesquisas nas relações sociedade e natureza, em uma abordagem da geografia histórica e da gestão de recursos na esfera regional. Em 1994 e 1995, Brannstrom esteve na Unesp/Assis consultando o Arquivo do Fórum da Comarca de Assis, disponível para consulta no Centro de Documentação e Apoio à Pesquisa. Brannstrom criou uma metodologia para o uso de documentação jurídica na história ambiental regional, que Menarin aproveitou de forma criteriosa, e que se apresenta agora como nova possibilidade para outras investigações.

O mergulho do autor nesta documentação oficial - leis, decretos, processos de ações judiciais, jornais - não prescindiu do seu conjunto de fontes de mapas e gráficos. O caráter multidisciplinar, peculiaridade das pesquisas da história ambiental, revela-se, entre outros aspectos, na linguagem técnica que o autor teve que manejar para extrair informações de um tema enfrentado apenas recentemente pelos historiadores. O glossário ao final do livro é testemunha desse desafio epistemológico e também instrumento indispensável para o leitor leigo.

O livro está dividido em cinco capítulos, além do glossário e um apêndice, que traz o diagnóstico colhido pelo autor junto a alunos de escolas públicas do município de Santa Rita do Passa Quatro. A pesquisa realizada com esse público serviu para colocar em evidência o distanciamento daquela comunidade em relação ao parque.

O primeiro capítulo introduz o leitor na história da política de proteção ambiental no Brasil. Ele aborda os marcos legais que regulamentaram a criação de espaços naturais protegidos, particularmente os parques. A reconstituição histórica remete a um imbróglio jurídico que contrapõe ações voltadas para a preservação ambiental ao direito de propriedade, processo no qual o autor identificou os principais obstáculos na implantação efetiva do Parque de Vassununga. A análise dirigiu-se, então, não apenas às deficiências institucionais e administrativas, mas, sobretudo, à questão fundiária pendente de regularização há mais de vinte anos, envolvendo os proprietários legais da área definida como parque e o próprio Estado, e para o fraco elo entre a comunidade local e aquela unidade de conservação.

O capítulo seguinte trata da história da ocupação e exploração do entorno do município de Santa Rita do Passa Quatro, uma área coberta por floresta estacional semidecídua, também denominada mata atlântica de interior, e pelo cerrado, que compõe o recorte espacial da pesquisa. Após conhecer todas as vicissitudes da formação socioeconômica e ambiental dessa região e do que restou dessa história em termos de patrimônio, o leitor é apresentado ao fato fundamental que desencadeou toda a trama analisada ao longo do livro: com a crise e posterior falência da Companhia Usina Vassununga, no final da década de 1960, o governo do estado de São Paulo arrematou em leilão a massa falida e criou, no local, o Parque Estadual de Vassununga.

O processo de falência da Companhia Usina Vassununga também deu ensejo ao poder público da cidade de indicar para a preservação alguns bens considerados de caráter histórico, pertencentes à usina, que deveriam compor o acervo do então recém-criado Museu Histórico e Pedagógico Zequinha de Abreu. Essa trama é desvendada no capítulo três, no qual Menarin procurou compreender o porquê de se efetivar apenas parcialmente a proteção das áreas 
naturais, com a criação do parque, e também de parte das peças de interesse público recolhidas ao museu.

Atrás de respostas, o autor encarou as várias páginas dos processos judiciais abertos para resolver a questão fundiária iniciada com o processo de falência da usina e a criação do Parque Estadual de Vassununga na área que integrava a massa falida. Neste ínterim, a Usina Santa Rita tornou-se proprietária dos bens da antiga Companhia Usina Vassununga. Apoiados no direito de propriedade, esses novos proprietários iniciaram uma ação de desapropriação indireta contra a Fazenda do estado pela criação do parque em sua propriedade. A ação indenizatória rendeu vultosa quantia de dinheiro público aos proprietários dessa nova usina.

Como se deu a operação de supervalorização das áreas naturais no processo judicial movido pelos advogados e peritos contratados pela Usina Santa Rita? Esse é o objeto do quarto capítulo. O autor identificou nesse impasse jurídico, técnico e burocrático, que ainda não havia terminado quando a pesquisa estava em curso, um dos principais obstáculos para a efetiva implantação da unidade de conservação.

À sombra dos jequitibás vai além da disputa jurídica que envolveu a implementação do Parque de Vassununga e o interesse privado. Menarin traz à tona a relevância do parque enquanto área de preservação de espécies animais e vegetais, remanescentes de uma biodiversidade espoliada durante décadas. E não apenas aponta para a incontroversa função ecológica desses espaços, mas também acentua sua função social, como instrumento indutor de ações que visam constituir uma consciência ambiental.

O quinto e último capítulo trata do lugar ocupado pelo Parque Estadual de Vassununga na sociedade santarritense. Menarin buscou aproximar do parque a imagem do jequitibárosa, símbolo do patrimônio ambiental da cidade. Descobriu que, não obstante a popularidade daquela árvore, apenas parte da população da cidade a identifica como pertencente ao Parque Estadual de Vassununga. Essa dissociação entre o 'jequitibá-símbolo' e a unidade de conservação é resultado e reflexo do demorado processo de implantação dessa área natural protegida. O livro, então, tem o duplo mérito de nos mostrar que o Parque Estadual de Vassununga foi criado à sombra do símbolo da cidade de Santa Rita de Passa Quatro, alheio à própria população local. Ele revela ainda as veias abertas pelos agentes do capital privado no corpo da administração pública brasileira.

Por fim, cabe reconhecer que a constante reinvenção da historiografia, atualizada pelas novas questões e problemáticas, é também seu trunfo para continuar a ser relevante. A pesquisa de Carlos Alberto Menarin é exemplo de saudável diversificação, e seu livro deve ser lido não apenas por especialistas e estudiosos do assunto, mas também por todos aqueles que estão preocupados com os rumos tomados pela política de proteção à natureza no Brasil.

\section{REFERÊNCIAS}

DEAN, Warren.

A ferro e fogo: a história e a devastação da Mata Atlântica brasileira. São Paulo: Companhia da Letras. 1996.
WORSTER, Donald.

Para fazer história ambiental. Estudos Históricos, Rio de Janeiro, v.4, n.8, p.198-215. 1991. 